\title{
PENGARUH KUALITAS SUMBER DAYA MANUSIA, SARANA PENDUKUNG DAN KOMITMEN PIMPINAN TERHADAP KINERJA SATUAN KERJA PERANGKAT DAERAH (SKPD) DALAM PENYUSUNAN LAPORAN KEUANGAN SKPD DI LINGKUNGAN PEMERINTAH PROVINSI SULAWESI UTARA
}

\author{
Brammy Pandey \\ (email: rigentdaryl@gmail.com)
}

\begin{abstract}
This study on the effect of human resources, means of support and commitment to the performance of work units (SKPD) in the preparation of financial statements in the North Sulawesi provincial government, such research is still relatively small, and the results of the study are still varied and inconsistent. The purpose of this research was conducted to find whether there is empirical evidence Effects of human resources, means of support and commitment to performance on education in the preparation of financial statements in Sulawesi Utara.Populasi this study are all available on education in the government of North Sulawesi province. The unit of analysis is the head of the organizational work units. Data was collected through questionnaires delivered directly by the author. Before testing the hypothesis with multiple regression analysis, prior testing and test data quality classical assumptions. The results showed that the partial human resources, means of support and commitment to influence performance on education.
\end{abstract}

Key words: Quality, Supporting Facilities, Commitment, SKPD Performance.

\section{PENDAHULUAN}

Undang-undang Nomor 32 Tahun 2004 tentang Pemerintah Daerah dan Undang-undang Nomor 33 Tahun 2004 tentang Perimbangan Keuangan antara Pemerintah Pusat dan Pemerintah Daerah menjadi tonggak awal dari otonomi daerah. Otonomi daerah merupakan upaya pemberdayaan daerah dalam dimiliki sesuai dengan kepentingan, prioritas, dan potensi daerah tersebut. Dengan berlakunya otonomi daerah, pengelolaan keuangan daerah sepenuhnya berada ditangan Pemerintah Daerah.

Beberapa peraturan terkait dengan implementasi otonomi daerah yang telah dikeluarkan adalah paket undang-undang bidang keuangan Negara yakni Undang undang Nomor 17 Tahun 2003 tentang Keuangan Negara, Undang undang Nomor 1 Tahun 2004 tentang Perbendaharaan Negara dan Undang undang Nomor 15 Tahun 2004 tentang Pemeriksaan Pengelolaan dan Tanggung Keuangan Negara. Dalam rangka mengimplementasikan perundangan-undangan bidang keuangan Negara/Daerah telah dikeluarkan berbagai aturan pelaksanaan dalam bentuk Peraturan Pemerintah (PP), antara lain PP Nomor 20 Tahun 2004 tentang Rencana Kerja Pemerintah, PP Nomor 21 Tahun 2004 tentang Rencana Kerja dan Anggaran Kementerian Negara/Lembaga, dan PP Nomor 24 Tahun 2004 tentang Standar Akuntansi Pemerintahan (SAP) sebagaimana telah diubah menjadi PP Nomor 71 Tahun 2010. Berkaitan dengan Pengelolaan Keuangan Daerah telah dikeluarkan Peraturan Pemerintah Nomor 58 Tahun 2005 tentang Pengelolaan Keuangan Daerah. Sebagai tindak lanjut dari PP Nomor 58 Tahun 2005, Menteri Dalam Negeri telah mengeluarkan Peraturan Menteri Dalam Negeri (Permendagri) Nomor 13 Tahun 2006 tentang Pedoman pengelolaan Keuangan Daerah, sebagaimana telah beberapa kali diubah terakhir dengan Permendagri Nomor 21 Tahun 2011 tentang Perubahan Atas Permendagri Nomor 13 Tahun 2006 tentang Pedoman Pengelolaan Keuangan Daerah. Peraturan ini khusus mengatur mengenai Pedoman Pengelolaan Keuangan Daerah yang baru, sesuai arah reformasi tata kelola keuangan daerah. Perubahan yang sangat mendasar dalam peraturan ini adalah bergesernya fungsi Ordonancering dari Dinas/Badan/Biro/Bagian Keuangan ke setiap Satuan Kerja perangkat Daerah (SKPD), dan SKPD sebagai accounting entity berkewajiban untuk membuat laporan keuangan SKPD.

Berdasarkan Undang Undang Nomor 1 Tahun 2004 tentang Perbendaharaan Negara pasal 51 ayat (2), kepala SKPD selaku Pengguna Anggaran harus menyelenggarakan akuntansi atas transaksi keuangan, asset, utang, dan ekuitas dana, termasuk transaksi pendapatan dan belanja, yang berada dalam tanggungjawabnya. Hal ini berarti bahwa setiap SKPD harus membuat laporan keuangan unit kerja. Pasal 
56 UU ini menyebutkan bahwa laporan keuangan yang harus dibuat oleh setiap unit kerja adalah Laporan Realisasi Anggaran, Neraca, dan Catatan Atas Laporan Keuangan, sedangkan yang menyusun Laporan Arus Kas adalah Kepala Satuan Kerja Pengelola Keuangan Daerah selaku Bendahara Umum Daerah. Melalui PP Nomor 71 Tahun 2010 tentang Standar Akuntansi Pemerintahan menyatakan basis akuntansi yang digunakan dalam laporan keuangan pemerintah daerah adalah basis akrual.

Berlakunya Peraturan menteri dalam negeri tentang Pedoman Pengelolaan Keuangan Daerah, merupakan implementasi terhadap paradigma baru yang berorientasi pada prestasi kerja diterapkan dalam Penyusunan APBD, Sistem Akuntansi dan Pengelolaan Keuangan Daerah. Untuk itu setiap pemerintah daerah harus dapat mempersiapkan diri untuk melakukan pengelolaan keuangan daerah sesuai dengan peraturan yang berlaku.

Pengelolaan Keuangan Daerah dalam Pelaksanaan APBD mengalami perubahan yang cukup fundamental dibandingkan dengan aturan-aturan sebelumnya, diantara perubahan tersebut adalah dilimpahkannya sebagian mekanisme pengelolaan keuangan di Dinas/Badan/Biro/Bagian Keuangan kepada SKPD, dengan memberikan tugas dan tanggungjawab penuh kepada pimpinan SKPD selaku Pengguna Anggaran/Kuasa Pengguna Anggaran (PA/KPA) untuk mengelola keuangan pada SKPD yang dipimpinnya. Tugas pimpinan SKPD selaku PA/KPA antara lain disebutkan merencanakan, melaksanakan/menatausahakan, pelaporan dan pertanggungjawaban serta pengawasan anggaran. Selanjutnya dalam Permendagri Nomor 13 Tahun 2006 Pasal 10 menyatakan Kepala SKPD selaku pejabat pengguna anggaran/pengguna barang mempunyai tugas sebagai berikut.

1. Menyusun RKA-SKPD

2. Menyusun DPA-SKPD

3. Melakukan tindakan yang mengakibatkan pengeluaran atas beban anggaran belanja

4. Melaksanakan anggaran SKPD yang dipimpimnya

5. Melakukan pengujian atas tagihan dan memerintahkan pembayaran

6. Melaksanakan pemungutan penerimaan bukan pajak

7. Mengadakan ikatan/perjanjiankerjasama dengan pihak lain dalam batas anggaran yang telah ditetapkan

8. Menandatangani Surat Perintah Membayar (SPM)

9. Mengelola utang dan piutang yang menjadi tanggungjawab SKPD yang dipimpimnya

10. Mengelola barang milik daerah/kekayaan daerah yang menjadi tanggungjawab SKPD yang dipimpimnya

11. Menyusun dan menyampaikan laporan keuangan SKPD yang dipimpimnya

12. Mengawasi pelaksanaan anggaran SKPD yang dipimpimnya

13. Melaksanakan tugas-tugas pengguna anggaran/pengguna barang lainnya berdasarkan kuasa yang dilimpahkan oleh kepala daerah.

Sehubungan dengan hal tersebut maka peran pimpinan SKPD dalam pengelolaan keuangan daerah akan memerlukan SDM yang professional.

Azhar (2007) telah melaksanakan penelitian teentang "faktor-faktor yang mempengaruhi keberhasilan penerapan Permendagri Nomor 13 Tahun 2006 tentang Pedoman Pengelolaan Keuangan Daerah pada Pemerintah Kota Banda Aceh:, penelitian ini menyimpulkan bahwa : Komitmen, Sumber daya manusia, Perangkat Pendukung dan Regulasi secara bersama-sama mempunyai pengaruh yang signifikan terhadap keberhasilan penerapan Permendagri Nomor 13 Tahun 2006, dan secara parsial Regulasi tidak mempengaruhi secara sifnifikan terhadap keberhasilan penerapan Permendagri Nomor 13 Tahun 2006.

Berdasarkan pengamatan dilingkungan Pemerintah Provinsi Sulawesi Utara kemampuan Pimpinan SKPD dalam pengelolaan keuangan daerah di masing-masing SKPD masih terdapat SKPD yang belum menyampaikan daftar/laporan hutang dan piutang SKPD selama tahun anggaran 2012, dan masih terdapat SKPD yang terlambat menyampaikan Laporan Keuangan SKPD tahun anggaran 2012 serta Laporan Realisasi Anggaran Bulanan SKPD. Dari data yang diperoleh pada Badan Pengelola Keuangan dan Barang Milik Daerah Provinsi Sulawesi Utara masih terdapat SKPD yang terlambat menyampaikan Rencana Kerja Anggaran (RKA-SKPD) dan Dokumen Pelaksanaan Anggaran SKPD (DPA-SKPD) kepada SKPKD selaku Pejabat Pengelola Keuangan Daerah (PPKD) untuk persetujuan dan pengesahan. 
Sedangkan dalam pelaksanaan belanja daerah masih adanya SKPD yang terlambat dalam menyampaikan Surat Pertanggungjawaban Fungsional (SPJ-Fungsional) kepada PPKD selaku BUD. Selain itu data Bidang Akuntansi SKPKD realisasi anggaran belanja (LRA) tahun anggaran 2011 adalah 89\%. Sedangkan tahun 2012 unaudited hanya sekitar 90\%. Ini menunjukkan realisasi anggaran SKPD belum maksimal termasuk realisasi anggaran di awal tahun 2013. SKPD yang terlambat menyampaikan laporan keuangan tahun 2012 yaitu Bappeda, Dinas Sosial, Dinas Pertanian, RSUD Noongan, Taman Budaya, Museum Negeri, Badan Pemberdayaan Perempuan dan Perlindungan Anak, Balai Pelatihan Teknis Pertanian, dan Balai Pengujian dan sertifikasi Hasil Perikanan. Disamping itu Pengelolaan Barang Milik Daerah (Aset SKPD) perlu mendapat perhatian khusus dari Pimpinan SKPD selaku Pengguna Barang sesuai dengan Peraturan Menteri Dalam Negeri Nomor 17 Tahun 2007 tentang Pedoman Pengelolaan Barang Milik Daerah.. Sedangkan dalam pelaksanaan belanja daerah masih adanya SKPD yang terlambat dalam menyampaikan Laporan Realisasi Anggaran Bulanan (LRA SKPD) kepada SKPKD selaku PPKD dan BUD..

Mengamati fenomena dan hasil penelitian diatas maka peneliti termotivasi untuk melakukan penelitian pengembangan tentang Kinerja Satuan Kerja Perangkat Daerah. Penelitian ini dibatasi pada Kinerja Keuangan Pimpinan SKPD dalam Penyusunan Laporan Keuangan Pemerintah Daerah, yang akan dilaksanakan pada SKPD di lingkungan Pemerintah Provinsi Sulawesi Utara. Adapun variabel yang akan digunakan dalam penelitian ini adalah Kualitas Sumber Daya Manusia (SDM Pimpinan), Sarana Pendukung, dan Komitmen Pimpinan SKPD yang diduga akan mendukung Kinerja SKPD dalam Penyusunan Laporan Keuangan Pemerintah Daerah.

Berdasarkan latarbelakang yang telah diuraikan diatas, maka rumusan masalah penelitian adalah "Apakah Kualitas Sumber Daya Manusia (SDM0, Sarana Pendukung dan Komitmen Pimpinan berpengaruh terhadap Kinerja SKPD”

\section{TINJAUAN PUSTAKA}

\section{Landasan Teori}

\section{Pengelolaan Keuangan Daerah}

Pengelolaan Keuangan Daerah adalah keseluruhan kegiatan yang meliputi perencanaan, pelaksanaan, penatausahaan, pelaporan, pertanggungjawaban, dan pengawasan keuangan daerah.

Keuangan daerah adalah semua hak dan kewajiban daerah dalam rangka penyelenggaraan Pemerintahan Daerah yang dapat dinilai dengan uang termasuk didalamnya segala bentuk kekayaan yang berhubungan dengan hak dan kewajiban daerah tersebut. (PP 58 Tahun 2005)

\section{Laporan Keuangan Pemerintah Daerah}

Laporan keuangan merupakan bentuk pertanggungjawaban atas kepengurusan sumber daya ekonomi yang dimiliki oleh suatu entitas. Laporan keuangan yang diterbitkan harus disusun sesuai dengan standar akuntansi yang berlaku agar laporan keuangan tersebut dapat dibandingkan dengan laporan keuangan periode sebelumnya atau dibandingkan dengan laporan keuangan entitas yang jelas. (PP 24 Tahun 2005)

Peraturan Menteri Dalam Negeri Nomor 13 Tahun 2006, tentang Pedoman Pengelolaan Keuangan Daerah, dalam ketentuan umumnya menyebutkan bahwa yang dimaksud dengan keuangan daerah adalah semua hak dan kewajiban daerah dalam rangka penyelenggaraan Pemerintah Daerah yang dapat dinilai dengan uang termasuk di dalamnya segala bentuk kekayaan yang berhubungan dengan hak dan kewajiban daerah tersebut. Selanjutnya dalam pasal 4 dikatakan pula bahwa, pengelolaan keuangan daerah dilakukan dengan tertib, taat pada peraturan perundang-undangan,efektif, efisien, ekonomis, transparan dan bertanggung jawab dengan memperhatikan asas keadilan, kepatutan dan manfaat untuk masyarakat.

Menurut Peraturan Pemerintah Nomor 24 Tahun 2005 tentang Standar Akuntansi Pemerintahan, bahwa laporan keuangan merupakan laporan terstruktur mengenai posisi keuangan dan transaksi-transaksi yang dilakukan oleh suatu entitas pelaporan. Entitas pelaporan dalam pemerintah adalah unit pemerintahan yang terdiri dari satu atau lebih entitas akuntansi yang menurut ketentuan perundangundangan wajib menyampaikan laporan pertanggungjawaban berupa laporan keuangan, yang terdiri dari: (a) Pemerintah Pusat, (b) Pemerintah Daerah, (c) Satuan organisasi di lingkungan pusat/daerah atau 
organisasi lainnya, jika menurut perundang-undangan satuan organisasi dimaksud wajib menyajikan laporan keuangan.

Berdasarkan Peraturan Menteri Dalam Negeri Nomor 13 Tahun 2006, Laporan Keuangan Pemerintah Daerah terdiri dari berikut ini.

1. Laporan Realisasi Anggaran

Laporan realisasi anggaran menyajikan ikhtisar sumber, alokasi dan pemakaiansumber daya ekonomi yang dikelola oleh pemerintah pusat/daerah, yang menggambarkan perbandingan antara anggaran dan realisasinya dalam satu periode pelaporan. Unsur yang dicakup secara langsung oleh laporan realisasianggaran terdiri dari pendapatan, belanja transfer dan pembiayaan.

2. Neraca

Neraca menggambarkan posisi keuangan suatu entitas pelaporan mengenai aset,kewajiban dan ekuitas dana pada tanggal tertentu. Aset adalah sumber ekonomi yang dikuasai dan/atau dimiliki oleh pemerintah sebagai akibat dari peristiwa masa lalu dan dari mana manfaat ekonomi dan/atau sosial di masa depan diharapkan dapat diperoleh, baik oleh pemerintah maupun masyarakat, serta dapat diukur dalam satuan uang, termasuk sumber daya non keuangan yang diperlukan untuk menyediakan jasa bagi masyarakat umum dan sumber-sumber daya yang dipelihara karena alasan sejarah dan budaya. Kewajiban adalah utang yang timbuldan peristiwa masa lalu yang penyelesaiannya mengakibatkan aliran keluar sumber daya ekonomi pemerintah. Ekuitas Dana adalah kekayaan bersih pemerintah yang merupakan selisih antara aset dan kewajiban pemerintah.

3. Laporan Arus Kas

Laporan arus kas menyajikan informasi kas sehubungan dengan aktivitas operasional, inventasi aset non keuangan, pembiayaan, dan transaksi non anggaran yang menggambarkan saldo awal,penerimaan,pengeluaran dan saldo akhir kas pemerintah pusat/daerah selama periode tertentu. Unsur yang mencakup dalam laporan arus kas terdiri dari penerimaan dan pengeluaran kas.

4. Catatan atas Laporan Keuangan

Catatan atas laporan keuangan meliputi penjelasan naratif atau rincian dari angka yang tertera dalam laporan realisasi anggaran, neraca dan laporan arus kas.Catatan atas laporan keuangan juga mencakup informasi tentang kebijakan akuntansi yang dipergunakan oleh entitas pelaporan dan informasi lain yang diharuskan dan dianjurkan untuk mengungkapkan di dalam Standar Akuntansi Pemerintahan serta ungkapan-ungkapan yang diperlukan untuk menghasilkan penyajian laporan keuangan secara wajar.

\section{Prinsip-prinsip Penyusunan Laporan Keuangan Daerah}

Dalam Peraturan Pemerintah Nomor 24 Tahun 2005 tentang StandarAkuntansi Pemerintahan dikemukakan bahwa ada delapan prinsip yang digunakan dalam akuntansi dan pelaporan keuangan pemerintahan yakni sebagai berikut.

a. Basis Akuntansi

Basis akuntansi yang digunakan dalam laporan keuangan pemerintah adalahberbasis kas untuk pengakuan pendapatan, belanja dan pembiayaan dalam laporanrealisasi anggaran dan basis akrual untuk pengakuan aset, kewajiban dan ekuitasdalam neraca.

b. Nilai Historis (Historical Cost)

Aset dicatat sebesar pengeluaran kas dan setara kas yang dibayar atau sebesarnilai wajar dari imbalan (consideration) untuk memperoleh aset tersebut pada saatperolehan. Kewajiban dicatat sebesar jumlah kas dan setara kas yang diharapkanakan dibayarkan untuk memenuhi kewajiban di mana yang akan datang dalampelaksanaan kegiatan pemerintah.

c. Realisasi (Realizition)

Bagi pemerintah, pendapatan yang telah diotorisasikan melalui anggaran pemerintah selama suatu tahun fiskal akan digunakan untuk membayar hutang dan belanja dalam periode tertentu.

d. Substansi Mengungguli Bentuk Formal (Substance Over Form)

Informasi dimaksudkan untuk menyajikan dengan wajar transaksi serta peristiwa lain yang seharusnya disajikan, maka transaksi atau peristiwa lain tersebut perlu dicatat dan disajikan sesuai dengan substansi dan realitas ekonomi, dan bukan hanya aspek formalitasnya. Apabila substansi transaksi 
atau peristiwa tidakkonsisten/berbeda dengan aspek formalitasnya, maka hal tersebut harus diungkap dengan jelas dalam catatan atas laporan keuangan.

e. Periodisitas (Periodicity)

Kegiatan akuntansi dan pelaporan keuangan entitas pelaporan perlu dibagi menjadi periode-periode pelaporan sehingga kinerja entitas dapat diukur dan posisi sumber daya akan dimilikinya dapat ditentukan. Periode utama yang digunakan adalah tahunan. Namun, periode bulanan, triwulan dan semesteran juga dianjurkan.

f. Konsistensi (Consistency)

Perlakuan akuntansi yang sama diterapkan pada kejadian yang serupa dari periode ke periode oleh suatu entitas pelaporan (prinsip konsistensi internal). Hal ini tidakberarti bahwa tidak boleh tidak perubahan dari satu metode akuntansi ke metode akuntansi yang lain. Metode akuntansi yang dipakai dapat diubah dengan syarat bahwa metode yang baru diterapkan mampu memberikan informasi yang lebih baik dibandingkan dengan metode lama. Pengaruh atas perubahan penerapan metode ini diungkapkan dalam catatan atas laporan keuangan.

g. Pengungkapan Lengkap (Full Disclosure)

Laporan keuangan menyajikan secara lengkap informasi yang dibutuhkan oleh pengguna. Informasi yang dibutuhkan oleh pengguna laporan keuangan dapat ditempatkan pada lembar muka (on the face) laporan keuangan atau catatan ataslaporan keuangan.

h. Penyajian Wajar (Fair Presentation)

Laporan keuangan menyajikan dengan wajar laporan realisasi anggaran, neraca,laporan arus kas dan catatan atas laporan keuangan. Pertimbangan sehat bagi penyusun laporan keuangan diperlukan ketika menghadapi ketidakpastian peristiwa atau keadaan tertentu. Ketidakpastian seperti itu diakui dengan mengungkapkan hakikat serta tingkatnya dengan menggunakan pertimbangan sehat dalam menyusun laporan keuangan. Pertimbangan sehat mengandung unsur kehati-hatian pada saat melakukan prakiraan dalam kondisi ketidakpastian sehingga aset atau pendapatan tidak dinyatakan terlalu tinggi dan kewajiban tidak dinyatakan terlalu rendah.

\section{Kinerja SKPD}

Menurut Mardiasmo (2004) pengukuran kinerja sector public dilakukan untuk memenuhi tiga maksud.Pertama, pengukuran kinerja sector public dimaksudkan untuk membantu perbaikan kinerja pemerintah yang berfokus kepada tujuan dan sasaran program unit kerja.Hal ini pada akhirnya dapat meningkatkan efisiensi dan efektifitas organisasi sector public dalam memberikan pelayanan public.Kedua, ukuruan kinerja sector public digunakan unutk pengalokasian sumber daya dan pembuatan keputusan.Ketiga, ukuran kinerja sector public dimaksudkan untuk mewujudkan pertanggungjawaban public dan memperbaiki komunikasi kelembagaan. Disamping itu pengukuran kinerja sangat penting untuk menilai akuntabilitas organisasi dan manajer dalam menghasilkan pelayanan public yang lebih baik. Akuntabilitas bukan sekedar kemampuan menunjukan bagaimana uang public dibelanjakan, akan tetapi meliputi kemampuan menunjukan bahwa uang public tersebut telah dibelanjakan secara ekonomis, efisien dan efektif. Peningkatan kinerja sector public merupakan hal yang bersifat komprehensif, dimana setiap SKPD sebagai pengguna anggaran (badan/dinas/biro/kantor) akan menghasilkan tingkat kinerja yang berbeda-beda sesuai dengan kemampuan dan rasa tanggungjawab yang mereka miliki. Semakin baik tingkat pengelolaan keuangan oleh pengguna anggaran, maka akan semakin tinggi tingkat kinerja SKPD.

Kinerja menurut Peraturan Pemerintah Nomor 58 Tahun 2005 Pasal 1 poin 35 adalah keluaran/hasil dari kegiatan/program yang akan atau telah dicapai sehubungan dengan penggunaan anggaran dengan kuantitas dan kualitas yang terukur. Program adalah penjabaran kebijakan SKPD dalam bentuk upaya yang berisi satu atau lebih kegiatan dengan menggunakan sumber daya yang disediakan untuk mencapai hasil yang terukur sesuai dengan misi SKPD. Kegiatan adalah bagian dari program yang dilaksanakan oleh satu atau lebih unit kerja pada SKPD sebagai bagian dari pencapaian sasaran terukur pada suatu program dan terdiri dari sekumpulan tindakan pengerahan sember daya baik yang berupa personal (sumber daya manusia), barang modal termasuk peralatan teknologi, dana, atau kombinasi dari beberapa atau kesemua jenis sumber daya tersebut sebagai masukan (input) untuk menghasilkan keluaran (output) dalam bentuk barang/jasa. 
Menurut Permendagri Nomor 13 Tahun 2006 Pasal 1 poin 10 : Satuan Kerja Perangkat Daerah yang selanjutnya disingkat SKPD adalah perangkat daerah pada pemerintah daerah selaku pengguna anggaran/pengguna barang. Kinerja merupakan suatu prestasi atau tingkat keberhasilan yang dicapai oleh individu atau suatu organisasi dalam melaksanakan pekerjaan pada suatu periode tertentu.

Otley (1999) dalam Mahmudi (2005 : 6) "Kinerja mengacu pada sesuatu yang terkait dengan kegiatan melakukan pekerjaan, dalam hal ini meliputi hasil yang akan dicapai kerja tersebut".

Kemisean et.al, (2004 : 491) mengungkapkan bahwa tiga konsep yang bisa dipergunakan untuk mengukur kinerja birokrasi/organisasi non bisnis, yakni responsivitas, responsiblitas, dan akuntabilitas. Dalam menilai kinerja organisasi pelayanan public, banyak indicator yang dapat dipergunakan, yaitu: (1) produktivitas; (2) kualitas layanan; (3) responsivitas; (4) responsibilitas; dan (5) akuntabilitas.

Dalam konteks organisasi pemerintah daerah, pengukuran kinerja SKPD dilakukan untuk menilai seberapa baik SKPD tersebut melakukan tugas pokok dan fungsi yang dilimpahkan kepadanya selama periode tertentu. Mahsun (2006 : 196), pengukuran kinerja Pemerintah Daerah (Pemda) harus mencakup pengukuran kinerja keuangan dan non keuangan. Hal ini terkait dengan tujuan organisasi Pemda. Indikator Kinerja Pemda, meliputi indicator input, indicator proses, indicator output, indicator outcome, indicator benefit dan indicator impact.

Pasal 10 ayat (3) Undang-Undang Nomor 17 Tahun 2003 serta Pasal 6 ayat (2) dan Pasal 56 ayat (2) Undang-Undang Nomor 1 Tahun 2004 menetapkan bahwa kepala satuan kerja perangkat daerah menyusun laporan keuangan yang terdiri dari laporan realisasi anggaran, neraca, dan catatan atas laporan keuangan. Laporan keuangan tersebut disampaikan kepada kepala satuan kerja pengelola keuangan daerah paling lambat dua bulan setelah tahun anggaran berakhir.

Peraturan Pemerintah Nomor 24 Tahun 2005 dan Permendagri 13 Tahun 2006 menyebutkan bahwa Sistem Akuntansi Pemerintah Daerah meliputi serangkaian prosedur mulai dariproses pengumpulan data, pencatatan, pengikhtisaran sampai dengan pelaporan keuangan dalam rangka pertanggungjawaban pelaksanaan APBD yang dapat dilakukan secara manual atau menggunakan aplikasi komputer, sehingga tiap-tiap entitas pelaporan dan entitas akuntansi yakni SKPD dan SKPKD harus mampu menjalankan sistem akuntansi keuangan daerah yang telah ditetapkan sekurang-kurangnya prosedur akuntansi penerimaan kas, prosedur akuntansi pengeluaran kas,prosedur akuntansi aset tetap/barang milik daerah dan prosedur akuntansi selain kas.

Setiap entitas pelaporan dan entitas akuntansi yakni SKPD dan SKPKD diharapkan mampu menyusun laporan keuangan Pemerintah Daerah yakni laporan realisasi anggaran, necara, laporan arus kas dan catatan atas laporan keuangan dengan baik dan benar berdasar peraturan dan perundangan yang berlaku. Kemampuan penyusunan laporan keuangan Pemerintah Daerah yang disusun oleh entitas pelaporan dan entitas akuntansi dalam hal ini SKPD dan SKPKD dapat diukur dengan ketepatan waktu pelaporan yakni 2 (dua) bulan setelah berakhirnya tahun anggaran (Permendagri Nomor 13 Tahun 2006).

\section{Kualitas Sumber daya manusia}

Menurut Matindas (2002 : 89) dalam Azhar (2007) menyatakan bahwa sumber daya manusia adalah kesatuan tenaga manusia yang dalam organisasi dan bukan hanya sekedar penjumlahan karyawankaryawan yang ada. Sebagai kesatuan, sumber daya manusia harus dipandang sebagai suatu sistem di mana tiap-tiap karyawan merupakan berfungsi untuk mencapai tujuan organisasi. Sumber daya manusia diukur berdasarkan latar belakang pendidikan yang diperoleh pegawai. Dalam kaitan dengan kemampuan penyusunan laporan keuangan, maka lebih efektif dalam penyusunan laporan keuangan adalah sumber daya manusia yakni pegawai yang dimiliki berlatar belakang pendidikan akuntansi.

Menurut Gaa and Thore (2004) dalam Aidil (2010) mengatakan bahwa pendidikan akuntansi selama ini memfokuskan pada dimensi pilihan kebijakan tetapi tidak memperhatikan nilai dan kredibilitas yang mempengaruhi pilihan tersebut. Kemudian Gaa and Thorne menyebutkan bahwa pada dasarnya akuntan memiliki tindakan berdasarkan nilai yang ada dalam pikiran mereka.

Pelatihan sebagai bagian dari pendidikan yang menyangkut proses belajar untuk memperoleh dan meningkatkan keterampilan di luar sistem pendidikan yang berlaku dalam waktu relatif singkat dengan metode yang lebih mengutamakan pada praktek daripada teori. Menurut Veithzal Rivai (2004: 226) dalam Aidil (2010), Pelatihan dalam proses sistematis mengubah tingkah laku pegawai untuk mencapai 
tujuan organisasi.Pelatihan berkaitan dengan keahlian dan kemampuan pegawai untuk melaksanakan pekerjaan saat ini. Pelatihan memiliki orientasi saat ini dan membantu pegawai untuk mencapai keahlian dan kemampuan tertentu agar berhasil guna dalam pekerjaannya.

Menurut Notoatmojo (2003) dalam Aidil (2010) bahwa pendidikan dan pelatihan adalah upaya untuk mengembangkan sumber daya manusia, terutama untuk mengembangkan kemampuan intelektual dan kepribadian manusia. Sehingga dengan adanya pelatihan diharapkan kemampuan atau keterampilan karyawan akan meningkat.

\section{Sarana Pendukung}

Sarana pendukung yang dimaksud dalam penelitian ini ialah ketersediaan perangkat pendukung yang akan membantu kinerja SKPD dalam penyusunan laporan keuangan serta yang berkaitan dengan kebutuhan SKPD. Perangkat pendukung adalah alat untuk mendukung terlaksananya kegiatan atau pekerjaan seperti komputer, software dan lain-lain.

Menurut Kenneth dan Jane (2005) dalam Azhar (2007),perangkat keras adalah perlengkapan fisik yang digunakan untuk aktivitas input, proses dan output dalam sebuah sistem akuntansi. Perangkat keras ini terdiri dari komputer yang memproses, perangkat penyimpanan dan perangkat untuk menghasilkan output serta media fisik untuk menghubungkan semua unit tersebut.Sedangkan perangkat lunak menurut Kenneth dan Jane adalah sekumpulan rincian instruksi pra program yang mengendalikan dan mengkoordinasi perangkat keras komponen di dalam sebuah sistem informasi.

Menurut Permendagri Nomor 13 Tahun 2006 Pasal 232 ayat (3) : Sistem akuntansi pemerintahan daerah meliputi serangkaian prosedur mulai dari proses pengumpulan data, pencatatan, pengikhtisaran, sampai dengan pelaporan keuangan dalam rangka pertanggungjawaban pelaksanaan APBD yang dapat dilakukan secara manual atau menggunakan aplikasi komputer.

\section{Komitmen Pimpinan}

Robbins dan Judge (2007) mendefinisikan komitmen sebagai suatu keadaan dimana seorang individu memihak organisasi serta tujuan-tujuan dan keinginannya untuk mempertahankan keangotaannya dalam organisasi. Sedangkan Mathis dan Jackson (dalam Sopiah, 155) mendefinisikan komitmen organisasional sebagai derajad dimana karyawan percaya dan mau menerima tujuan-tujuan organisasi dan akan tetap tinggal atau tidak akan meninggalkan organisasinya).

Komitmen terhadap organisasi artinya lebih dari sekedar keanggotaan formal, karena meliputi sikap menyukai organisasi dan kesediaan untuk mengusahakan tingkat upaya yang tinggi bagi kepentingan organisasi demi pencapaian tujuan. Berdasarkan definisi ini, dalam komitmen organisasi tercakup unsur loyalitas terhadap organisasi, keterlibatan dalam pekerjaan, dan identifikasi terhadap nilai-nilai dan tujuan organisasi.Rendahnya komitmen mencerminkan kurangnya tanggung jawab seseorang dalam menjalankan tugasnya. Mempersoalkan komitmen sama dengan mempersoalkan tanggung jawab, dengan demikian, ukuran komitmen seorang pimpinan yang dalam hal ini adalah kepala sekolah adalah terkait dengan pendelegasian wewenang (empowerment). Dalam konsep ini pimpinan dihadapkan pada komitmen untuk mempercayakan tugas dan tanggung jawab ke bawahan. Sebaliknya, bawahan perlu memiliki komitmen untuk meningkatkan kompetensi diri.

Dari beberapa definisi yang diuraikan di atas dapat disimpulkan bahwa komitmen merupakan suatu ikatan psikologis karyawan pada organisasi ditandai dengan adanya :

1. Kepercayaan dan penerimaan yang kuat terhadap tujuan dan nilai-nilai organisasi

2. Kemauan untuk mengusahakan tercapainya kepentingan organisasi

3. Keinginan yang kuat untuk mempertahankan kedudukan sebagai anggota organisasi.

Menurut Mayer et. Al (1993), yang dikutip oleh Arifuddin et.al (2002) terdapat tiga komponen komitmen organisasi, yaitu:

1. Komitmen efektif (effective commitment) terjadi apabila karyawan ingin menjadi bagian dari organisasi karena adanya ikatan emosional (emotional attachment);

2. Komitment kontinuan (continuance commitment) terjadi apabila karyawan tetap bertahan pada suatu organisasi karena membutuhkan gaji dan keuntungan-keuntungan lain atau karena karyawan tersebut tidak menemukan pekerjaan lain. 
3. Komitmen normatif (normative commitment) timbul dari nilai-nilai karywan. Karyawan bertahan menjadi anggota organisasi karena ada kesadaran bahwa berkomitmen terhadap organisasi merupakan hal yang harus dilakukan.

\section{Penelitian Terdahulu}

Penelitian Azhar (2007) tentang Faktor-faktor yang Mempengaruhi Keberhasilan Penerapan Permendagri Nomor 13 Tahun 2006 pada Pemerintah Kota Banda Aceh. Hasil penelitian yang didapatkan pada Pemerintah Kota Banda Aceh menyimpulkan bahwa secara parsial variabel Komitmen, SDM dan Perangkat Pendukung berpengaruh terhadap keberhasilan penerapan Permendagri 13 Tahun 2006 sedangkan variabel regulasi tidak berpengaruh.

Penelitian Sulani (2009) tentang Faktor-faktor yang Mendukung Keberhasilan Penerapan PP 24 Tahun 2005 Kabupaten Labuhan Batu. Hasil penelitian menemukan bahwa secara parsial variabel Komitmen berpengaruh terhadap keberhasilan penerapan PP 24 Tahun 2005 di Kabupaten Labuhan Batu sedangkan variabel Sumber Daya Manusia dan Perangkat Pendukung tidak berpengaruh.

Penelitian Warisno (2009) tentang Faktor-faktor yang Mempengaruhi Kinerja SKPD di Lingkungan Pemerintah Provinsi Jambi. Hasil penelitian menunjukkan bahwa secara parsial variabel SDM dan Komunikasi berpengaruh terhadap Kinerja SKPD di Pemerintah Provinsi Jambi, sedangkan variabel Sarana Pendukung dan Komitmen tidak pengaruh.

Penelitian Aidil (2010) tentang Faktor-faktor yang Mempengaruhi Kemampuan Penyusunan Laporan Keuangan Pemerintah Daerah (Studi Empiris pada Pemerintah Kota Tebing Tinggi). Hasil penelitian menunjukkan bahwa secara parsial variabel Perangkat Pendukung berpengaruh terhadap Kemampuan Penyusunan Laporan Keuangan Pemerintah Daerah di Kota Tebing Tinggi sedangkan variabel Peraturan, Latar Belakang Pendidikan, Pelatihan dan Komitmen tidak berpengaruh.

Persamaan dengan penelitian ini yaitu terdapat pada variabel independen dan dependen. Sebaliknya perbedaan dengan penelitian ini adalah pada lokasi penelitian dan waktu penelitian

\section{KERANGKA KONSEPTUAL}

Berdasarkan rumusan masalah dan landasan teori, maka didefinisikan tiga variabel independen(X) yakni kualitas sumber daya manusia, sarana pendukung dan komitmen pimpinan yang diduga secara parsial berpengaruh terhadap kinerja SKPD dalam penyusunan laporan keuangan (Y).

Adapun kerangka konseptual dapat digambarkan pada Gambar 3.1 berikut:

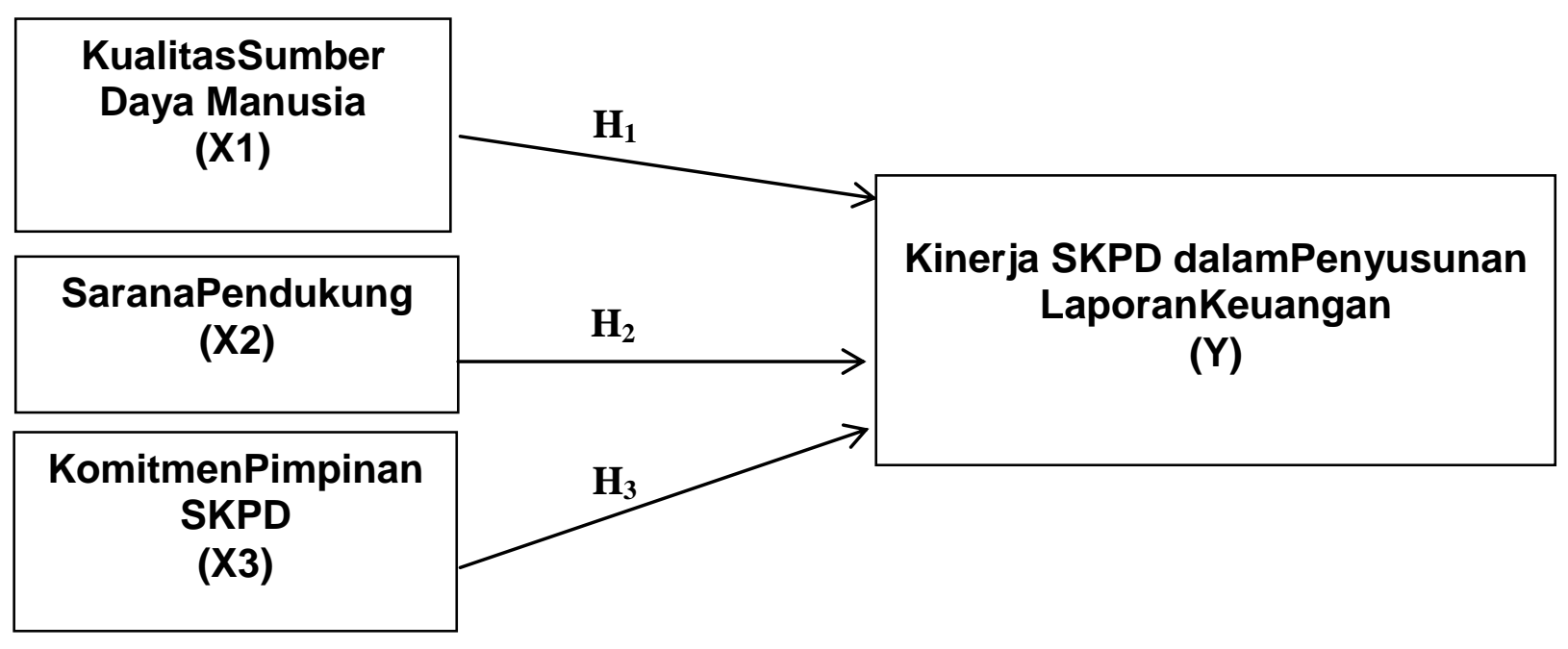

\section{Hipotesis}

Berdasarkan permasalahan yang telah dikemukakan sebelumnya dan kerangka konseptual tersebut diatas, maka dapat dirumuskan hipotesis sebagai berikut:

1. Pengaruh variabel kualitas sumber daya manusia terhadap Kinerja SKPD dalam Penyusunan Laporan Keuangan Daerah 
Variabel kualitas sumber daya manusia berpengaruh terhadap Kinerja SKPD dalam Pengelolaan Keuangan Daerah. Menurut Halim, dkk (2010), kualitas dan kinerja organisasi sangat ditentukan oleh faktor sumber daya manusia, karena keberadaan manusia dalam suatu organisasi tidak dapat digantikan oleh unsur lainnya. Organisasi dapat mencapai sukses apabila dikelola dengan baik, oleh karenanya diperlukan suatu manajemen sumber daya manusia yang efektif.

Penelitian Azhar (2007) bahwa sumber daya manusia berpengaruh terhadap keberhasilan penerapan Permendagri 13 Tahun 2006 karena sumber daya manusia merupakan elemen organisasi yang sangat penting dan harus dikelola sebaik mungkin agar mampu memberikan kontribusi secara optimal dalam upaya pencapaian tujuan organisasi.

$\mathrm{H}_{1}$ : Sumber daya manusia berpengaruh terhadap Kinerja SKPD dalam Penyusunan Laporan Keuangan.

2. Pengaruh variabel Sarana pendukung terhadap Kinerja SKPD dalam Penyusunan Laporan Keuangan

Variabel sarana pendukung berpengaruh terhadap Kinerja SKPD dalam Penyusunan Laporan Keuangan. Menurut Halim (2007), Sarana pendukung berupa komputer yang digunakan untuk menjalankan sistem akuntansi untuk meningkatkan efisiensi di dalam pemrosesan data transaksi seharihari sehingga memudahkan dalam penyajian laporan keuangan tepat waktu.

Penelitian Aidil (2010), perangkat pendukung berpengaruh terhadap penyusunan laporan keuangan. Pemerintah daerah dengan bantuan alat untuk mendukung terlaksananya kegiatan atau pekerjaan seperti adanya perangkat keras komputer dan perangkat lunak sehingga dalam pelaksanaan pekerjaan lebih efisien dan lebih tepat waktu dalam penyajian laporan keuangan pemerintah daerah.

$\mathrm{H}_{2}$ : Sarana Pendukung berpengaruh terhadap kemampuan Kinerja SKPD dalam Penyusunan Laporan Keuangan.

3. Pengaruh variabel komitmen terhadap Kinerja SKPD dalam Penyusunan Laporan Keuangan

Variabel komitmen berpengaruh terhadap Kinerja SKPD dalam Penyusunan Laporan Keuangan. Menurut Halim, dkk (2010), bahwa pentingnya komitmen pejabat pengelola keuangan daerah untuk penyelenggaraan akuntansi dan pelaporan keuangan untuk menghasilkan laporan keuangan yang handal dan tepat waktu.

Penelitian Azhar (2007) bahwa komitmen berpengaruh terhadap penerapan Permendagri 13 Tahun 2006 karena semakin tinggi komitmen dari anggota organisasi maka semakin berhasil dalam penerapan Permendagri 13 Tahun 2006 demikian juga dalam hal penyusunan laporan keuangan pemerintah daerah. $\mathrm{H}_{3}$ : Komitmen berpengaruh terhadap Kinerja SKPD dalam Penyusunan Laporan Keuangan.

\section{Model Analisis}

Dalam penelitian ini, pengujian terhadap hipotesis 1 sampai dengan hipotesis 3, dengan tehnik analisis regresi linier berganda. Menurut Sugiyono (2011), analisis regresi linier berganda digunakan oleh peneliti bila peneliti bermaksud meramalkan bagaimana keadaan (naik turunnya) variabel dependen bila dua atau lebih variabel independen sebagai faktor prediktor dimanipulasi (dinaik turunkan nilainya) dengan menggunakan formula sebagai berikut :

Dimana :

$$
\mathbf{Y}=\alpha+\beta_{1} \mathbf{X}_{1}+\beta_{2} X_{2}+\beta_{3} X_{3}+\varepsilon
$$

$\begin{array}{ll}\mathrm{Y} & =\text { Kinerja SKPD dalam Penyusunan Laporan Keuangan } \\ \alpha & =\text { Konstanta } \\ \beta_{1}, \beta_{2}, \beta_{3} . & =\text { Koefisien Regresi } \\ \mathrm{X}_{1} & =\text { Sumber Daya Manusia } \\ \mathrm{X}_{2} & =\text { Sarana Pendukung } \\ \mathrm{X}_{3} & =\text { Komitmen } \\ \varepsilon & =\text { Error }\end{array}$




\section{Metode Penelitian}

\section{Jenis/Rancangan Penelitian}

Jenis data yang digunakan dalam penelitian ini adalah kualitatif yang dikuantitatifkan. Menurut Sugiyono (2011) metode kuantitatif adalah cara ilmiah untuk mendapatkan data penelitian dalam bentuk angka - angka dan analisis menggunakan statistik. Sumber data yang digunakan dalam penelitian ini adalah :

a. Data primer yaitu berupa kuesioner yang di berikan kepada responden pada seluruh SKPD di lingkungan Pemerintah Provinsi Sulawesi Utara.

b. Data sekunder yaitu berupa literatur - literatur kepustakaan yang digunakan sebagai dasar teori yang relevan dengan masalah yang diteliti dan penelitian - penelitian sebelumnya.

\section{Populasi dan Sampel Penelitian}

Populasi dalam penelitian ini adalah seluruh SKPD di lingkungan Pemerintah Provinsi Sulawesi Utara dengan jumlah 48 SKPD dan Unit Kerja, yang terdiri dari 14 Badan, 16 Dinas, 9 Biro, 2 Rumah Sakit Daerah, dan 2 kantor. Dimana masing-masing SKPD akan diberikan 1 (satu) kuisioner yang akan diisi oleh Pengguna Anggaran atau Kuasa Pengguna Anggaran SKPD, sehingga total populasi yang akan diberikan kuisioner sebanyak 48 populasi. Populasi dalam penelitian ini merupakan sampel yaitu sebanyak 48 sampel karena dilakukan dengan menggunakan metode sensus.

\section{Definisi Operasional dan Pengukuran Variabel}

Penelitian ini akan menggunakan tiga variabel independen (Kualitas Sumber Daya Manusia, Sarana Pendukung dan Komitmen Pimpinan) dan satu variabel dependen yaitu Kinerja SKPD dalam Penyusunan Laporan Keuangan Daerah.

1. Kinerja SKPD dalam Penyusunan Laporan Keuangan Daerah berdasarkan peraturan dan perundang-undangan yang berlaku diartikan sebagai kemampuan dari masing-masing pimpinan SKPD dalam menyusun laporan keuangan Pemerintah Daerah yang terdiri dari Laporan Realisasi Anggaran, Neraca, Catatan atas Laporan Keuangan sesuai dengan Standar Akuntansi Pemerintahan. Variabel ini diukur dengan menggunakan kuesioner dengan 7 (tujuh) pertanyaan dan diukur dengan skala Likert1-5 untuk setiap bobot pertanyaan.

2. Kualitas sumber daya manusia adalah kesatuan tenaga manusia pada pimpinan SKPD dengan pengalaman mengelola keuangan, pendidikan dan kompetensi disertai dengan kematangan usia diperlukan oleh pimpinan SKPD. Disamping itu pemahaman peran tugas dan tanggungjawab serta terus meningkatkan keahlian dan intelengsi untuk mencapai tujuan organisasi dalam penyusunan laporan keuangan SKPD.Variabel ini diukur dengan skala Likert 1-5 untuk setiap bobot pertanyaan.

3. Sarana pendukung dalam penelitian ini adalah ketersediaan perangkat pendukung yang akan membantu dalam melaksanakan tugas seperti ketersediaan perangkat komputer dan software yang berkaitan dengan efisiensi dan kemudahan pemahaman serta kapasitas jaringan untuk mengoperasikan perangkat komputer tersebut. Variabel ini diukur dengan skala Likert 1-5 untuk setiap bobot pertanyaan.

4. Komitmen artinya adalah kepercayaan diri, semangat kerja, dan kreatifitas, kepribadian moral serta fisik yang kuat juga bersikap positif dalam kejelasan peran dari pimpinan SKPD selaku entitas akuntansi untuk menyusun laporan keuangan pemerintah daerah.. Variabel ini diukur dengan skala Likert 1-5 untuk setiap bobot pertanyaan.

\section{Metode Analisis Data}

Dalam penelitian ini hipotesis yang diajukan untuk menemukan apakah ada pengaruh kualitas sumber daya manusia, sarana pendukung, dan komitmen pimpinan terhadap Kinerja SKPD dalam Penyusunan Laporan Keuangan Pemerintah Daerah.

Untuk menguji hipotesis yang diajukan, akan dilakukan dengan menganalisis regresi berganda (multiple regresion analysis) dengan metode Ordinary Least Square (OLS). Regresi berganda digunakan untuk menguji pengaruh kualitas sumber daya manusia, sarana pendukung dan komitmen pimpinan terhadap Kinerja SKPD dalam Penysunan laporan Keuangan Pemerintah Daerah. 
Untuk menguji hipotesis dilakukan dengan langkah-langkah sebagai berikut.

1. Menentukan besarnya koefisien regresi dari persamaan regresi.

2. Melakukan uji t untuk menentukan tingkat signifikansi pengaruh variabel independen secara individual terhadap variabel dependen yang menganggap variabel lain bersifat konstan.
$\mathrm{H}_{0}: \beta_{1}=0$,
artinya Kualitas Sumber daya Manusia tidak berpengaruh terhadap Kinerja SKPD dalam Penyusunan Laporan Keuangan Pemerintah Daerah.
$\mathrm{H}_{\mathrm{a}}: \beta_{1} \neq 0, \quad$ artinya Kualitas Sumber daya Manusia berpengaruh terhadap Kinerja SKPD dalam Penyusunan Laporan Keuangan Pemerintah Daerah.
$\mathrm{H}_{0}: \beta_{2}=0$, artinya Sarana pendukung tidak berpengaruh terhadap Kinerja SKPD dalam Penyusunan Laporan Keuangan Pemerintah Daerah.
$\mathrm{H}_{\mathrm{a}}: \beta_{2} \neq 0$, artinya Sarana Pendukung berpengaruh terhadap Kinerja SKPD dalam Penyusunan
$\mathrm{H}_{0}: \beta_{3}=0$, Laporan Keuangan Pemerintah Daerah.
$\mathrm{H}_{\mathrm{a}}: \beta_{3} \neq 0$, artinya Komitmen tidak berpengaruh terhadap Kinerja SKPD dalam Penyusunan Laporan Keuangan Pemerintah Daerah.
artinya Komitmen berpengaruh terhadap Kinerja SKPD dalam Penyusunan Laporan Keuangan Pemerintah Daerah.

Uji ini dilakukan untuk membandingkan nilai t-hitung dengan nilai t-tabel. Apabila t-hitung > ttabel dengan tingkat keyakinan (level of significant) misalnya sebesar 99\% maka $\mathrm{H}_{\mathrm{a}}$ diterima dan $\mathrm{H}_{0}$ ditolak, sebaliknya t-hitung < t-tabel maka $\mathrm{H}_{\mathrm{a}}$ ditolak dan $\mathrm{H}_{0}$ diterima. Dapat juga dilihat dari tingkat signifikansi yaitu hasil signifikansi $<\alpha 0,05$ maka $\mathrm{H}_{\mathrm{a}}$ diterima atau $\mathrm{H}_{0}$ ditolak. Sebaliknya apabila tingkat signifikansi $>\alpha 0,05$ maka $\mathrm{H}_{\mathrm{a}}$ ditolak atau $\mathrm{H}_{0}$ diterima.

3. Melakukan uji $\mathrm{F}$ untuk menentukan tingkat signifikansi pengaruh variabel-variabel independen secara menyeluruh terhadap variabel dependen. Pengujian hipotesis dangan menggunakan uji $\mathrm{F}$ atau bisa disebut dengan Analysis Of Varian (Anova). Pengujian Anova dapat dilakukan denga dua cara yaitu dengan membandingkan antara F-hitung dengan F-tabel atau melihat tingkat signifikansi pada tabel Anova.

Pengujian dengan membandingkan nilai F-hitung dangan F-tabel dilakukan dengan ketentuan yaitu apabila F-hitung > dari F-tabel $(\alpha) 0,05$ maka $\mathrm{H}_{1}$ diterima dan $\mathrm{H}_{0}$ ditolak, dan sebaliknya apabila Fhitung < dari F-tabel $(\alpha) 0,05$ maka $\mathrm{H}_{1}$ ditolak dan $\mathrm{H}_{0}$ diterima. Pengujian dengan tingkat signifikansi dilakukan dengan ketentuan apabila hasil signifikansi pada tabel Anova $<\alpha 0,05$ maka $\mathrm{H}_{1}$ diterima atau $\mathrm{H}_{0}$ ditolak. Sebaliknya apabila tingkat signifikansi pada tabel Anova $>\alpha 0,05$ maka $\mathrm{H}_{1}$ ditolak atau $\mathrm{H}_{0}$ diterima.

4. Menentukan besarnya nilai koefisien determinasi $(\mathrm{R})$ yang bertujuan untuk mengetahui seberapa besar kemampuan variabel independen menjelaskan variabel dependen. Nilai $\mathrm{R}$ mempunyai interval nilai mulai dari 0 sampai $1(0 \leq \mathrm{R} \leq 1)$, semakin besar $\mathrm{R}$ (mendekati 1$)$, semakin baik model regresi tersebut. Semakin mendekati 0 maka variabel independen secara keseluruhan tidak dapat menjelaskan variabel dari variabel dependen. Untuk regresi linier berganda sebaiknya menggunakan nilai R Square yang disesuaikan atau Adjusted R Square. Nilai R Square maupun Adjusted R Square dikatakan baik jika nilai diatas 0,5 (Lubis, dkk, 2007) dalam Aidil (2010).

\section{ANALISIS DAN PEMBAHASAN HASIL PENELITIAN \\ Pengaruh Variabel Kualitas Sumber Daya Manusia terhadap Kinerja SKPD dalam Penyusunan Laporan Keuangan Pemerintah Daerah}

Pada penelitian ini variabel kualitas sumber daya manusia (X1) berpengaruh terhadap Kinerja SKPD dalam penyusunan laporan keuangan. Semakin baik tingkat pendidikan dan semakin sering mengikuti pelatihan pengelolaan keuangan daerah maka semakin baik laporan keuangan yang dihasilkan. Penyajian laporan keuangan pemerintah daerah lebih efektif disajikan dengan kualitas sumber daya manusia yang memiliki latar belakang pendidikan akuntansi.

Dalam rangka pengelolaan keuangan daerah yang baik, aparat SKPD harus memiliki kualitas sumber daya manusia yang didukung dengan pengalaman, pendidikan, kematangan usia, pemahaman atas tupoksi, peningkatan keahlian, tingkat intelegensia serta kepuasan kerja di bidang keuangan.Pelatihan itu 
penting bagi pegawai. Sebagaimana menurut Veithzal Rivai (2004) dalam Aidil (2010), pelatihan dalam proses sistematis mengubah tingkah laku pegawai untuk mencapai tujuan organisasi. Pelatihan berkaitan dengan keahlian dan kemampuan pegawai untuk melaksanakan pekerjaan saat ini.Pelatihan memilikiorientasi saat ini dan membantu pegawai untuk mencapai keahlian dan kemampuantertentu agar berhasil guna dalam pekerjaannya.Sedangkan menurut Notoatmojo (2003) dalam Aidil (2010) menyatakan bahwa pendidikan dan pelatihan adalah upaya untukmengembangkan sumber daya manusia, terutama untuk mengembangkan kemampuan intelektual dan kepribadian manusia. Sehingga dengan adanya pelatihan diharapkan kemampuan atau keterampilan karyawan akan meningkat.

Penelitian ini sejalan dengan penelitian Azhar (2007) sumber daya manusia berpengaruh terhadap Kinerja SKPD dalam penyusunan laporan keuangan karena kualitas sumber daya manusia merupakan elemen organisasi yang sangat penting dan harus dikelola sebaik mungkin agar mampu memberikan kontribusi secara optimal dalam upaya pencapaian tujuan organisasi.

\section{Pengaruh Variabel Sarana Pendukung terhadap Kinerja SKPD dalam Penyusunan Laporan Keuangan Pemerintah Daerah}

Hasil penelitian ini menyatakan bahwa variabel perangkat pendukung (X2) berpengaruh terhadap Kinerja SKPD dalam penyusunan laporan keuangan. Perangkat pendukung adalah alat untuk mendukung terlaksananya kegiatanatau pekerjaan seperti 71oordina, software dan lain-lain. Menurut Kenneth dan Jane(2005) kegunaan perangkat keras merupakan perlengkapan fisik yang digunakan untuk aktivitas input, proses dan output dalam sebuah 71oordi akuntansi. Denganadanya perangkat keras yang memadai maka output dapat dihasilkan.

Output dihasilkan secara memadai maka siklus akuntansi dapat dijalankan sehingga dapat mendukung kemampuan penyusunan laporan keuangan pemerintah daerah.Dengandemikian hasil dari penelitian ini yang menunjukkan terdapat pengaruh sarana pendukung dalam mendukung penyelesaian tugas SKPD dalam menyusun laporan keuangan. Laporan yang dihasilkan merupakan output dari serangkaian proses darisebuah siklus akuntansi yang menghasilkan laporan keuangan. Namun dalam penelitian ini mempunyai hubungan yang tidak searah karena berubahnya teknologi membuat kepala SKPD sering tidak beradaptasi dengan baik atas perubahan teknologi yang cepat. Bergantinya 71 oordi administrasi berbasis manual menjadi berbasis 71oordina menyebabkan berubah pula pengendalian intern, metode pencatatan, metode penyimpanan, metode penelusuran dan fungsi-fungsi lainnya. Perubahan tersebutperlu diikuti berubahnya kompetensi dan kualifikasi karyawan agar mampu menjalankan tugasnya dengan baik dan dapat beradaptasi dengan perubahan system informasi untuk menunjang pekerjaannya.

Goodhue dan Thompson (1995) dalam Aidil (2010) menjelaskan bahwa hubungan antara 71oordi kesesuaian tugas-teknologi terhadap kinerja individual didasarkan pada penelitian-penelitian yang berfokus pada kesesuaian tugas-teknologi.Dalam penelitian tersebut, pemanfaatan teknologi informasi merupakan sesuatu yang sudah diasumsikan. Aliran yang berfokus pada kesesuaian tugas-tekonologi iniberargumentasi bahwa dampak kinerja akan dihasilkan dari kesesuaian tugas teknologi, yaitu pada saat teknologi menyediakan sarana dan dukungan yang sesuai atau cocok dengan yang diperlukan oleh tugas yang didukungnya. Artinya jika teknologi yang diterapkan dalam suatu perusahaan dapat memberikan banyak kemudahan dalam penyelesaian tugas/pekerjaan, maka kinerja individu karyawan pada perusahaan tersebut meningkat.Pandangan aliran penelitian yang berfokus padatugas teknologi perangkat pendukung.

Penelitian ini tidak sejalan dengan Sulani (2009) bahwa perangkat pendukung tidak berpengaruh karena di Kabupaten Labuhan Batu masih menggunakan jasa konsultan dalam penyusunan laporan keuangan.

\section{Pengaruh Variabel Komitmen terhadap Kinerja SKPD dalam Penyusunan Laporan Keuangan Pemerintah Daerah}

Pada penelitian ini variabel komitmen pimpinan(X3) berpengaruh terhadap Kinerja SKPD penyusunan laporan keuangan pemerintah daerah. Robbins dan Judge (2007) mendefinisikan komitmen sebagai suatu keadaan dimana seorang individu memihak organisasi serta tujuan-tujuan dan keinginannya untuk mempertahankan keangotaannya dalam organisasi. Dimana karyawan percaya dan mau menerima 
tujuan-tujuan organisasi dan akan tetap tinggal atau tidak akan meninggalkan organisasinya.Tanpa adanya komitmen maka pekerjaan-pekerjaan besar akan sulit terlaksana. Kesanggupan untuk bertanggung jawab terhadap hal-hal yang dipercayakan kepada seseorang. Komitmen tidak ada hubungannya sama sekali dengan bakat, kepintaran atau talenta. Komitmen yang kuat akan memungkinkan seseorang 72oor mengeluarkan sumber daya fisik, mental, dan spiritual tambahan yang 72oor diperoleh, sebaliknva tanpa komitmen maka pekerjaan-pekerjaan besar akan sulit dilaksanakan.

Penelitian ini tidak sejalan dengan penelitian Aidil (2010) yang mengata hwa komitmen tidak berpengaruh terhadap kemampuan penyusunan laporan keuangan disebabkan para pegawai yang terkait belum bisa mengeluarkan sumber daya fisik, mental dan spiritual tambahan dalam melaksanakan penugasannya.

\section{SIMPULAN DAN SARAN \\ Simpulan}

Penelitian ini bertujuan untuk mengetahui pengaruh kualitas sumber daya manusia, sarana pendukung, dan komitmen pimpinan terhadap kinerja keuangan dalam pengelolaan keuangan daerah untuk penyusunan laporan keuangan pada Pemerintah Provinsi Sulawesi Utara. Berdasarkan hasil penelitian maka dapat diambil simpulan sebagai berikut :

1. Kualitas sumber daya manusia berpengaruh terhadap kinerja keuangan pimpinan SKPD dalam pengelolaan keuangan daerah untuk penyusunan laporan keuangan, sehingga semakin baik tingkat pendidikan dan semakin sering mengikuti pelatihan pengelolaan keuangan daerah maka semakin baik laporan keuangan yang dihasilkan. Penyajian laporan keuangan pemerintah daerah lebih efektif disajikan dengan kualitas sumber daya manusia yang memiliki latarbelakang pendidikan akuntansi.

2. Perangkat/Sarana pendukung berpengaruh terhadap kinerja keuangan pimpinan SKPD dalam pengelolaan keuangan daerah untuk penyusunan laporan keuangan.Hal ini menunjukkan laporan yang dihasilkan merupakan output dari serangkaian proses siklus akuntansi yang menghasilkan laporan keuangan.

3. Komitmen pimpinan berpengaruh terhadap kinerja keuangan pimpinan SKPD dalam pengelolaan keuangan daerah untuk penyusunan laporan keuangan. Dengan komitmen yang kuat akan memungkinkan seseorang 72oor mengeluarkan sumber daya fisik, mental, dan spiritual tambahan yang 72oor diperoleh. Tanpa adanya komitmen maka pekerjaan-pekerjaan besar akan sulit terlaksana.

\section{Saran}

Berdasarkan hasil penelitian yang telah dilakukan maka diajukan saran sebagai berikut :

1. Peneliti menyarankan untuk penelitian selanjutnya agar memperluas objek penelitian pada pengelola keuangan daerah se-Provinsi Sulawesi Utara sehingga hasilnya dapat digeneralisasi.

2. Bagi pimpinan SKPD sebagai pengguna anggaran/pengguna barang agar memiliki rasa tanggungjawab dalam penyusuanan laporan keuangan di SKPD sesuai dengan tugas pokok dan fungsinya. Semakin baik tingkat kewajaran penyusunan laporan keuangan, maka akan semakin tinggi tingkat kinerja SKPD.

3. Bagi Gubernur yang adalah pemegang kekuasaan pengelolaan keuangan daerah, Sekretaris Daerah selaku 72oordinator pengelolaan keuangan daerah, dan Kepala Satuan Kerja Pengelola Keuangan Daerah (SKPKD) selaku Pejabat Pengelola Keuangan Daerah (PPKD) agar melaksanakan pembinaan pengelolaan keuangan daerah kepada Kepala SKPD serta memberikan petunjuk teknis dalam mengelola APBD yang ada di SKPD masing-masing.

\section{DAFTAR PUSTAKA}

Azhar, 2007, Faktor-faktor yang mempengaruhi Keberhasilan Penerapan Permendagri Nomor 13 Tahun 2006 pada Pemerintah Kota Banda Aceh.

Mardiasmo, 2004, Akuntansi Sektor Publik. Edisi Pertama, Penerbit Andi Yogyakarta.

Menteri Dalam Negeri, Peraturan Menteri Dalam Negeri Nomor 13 Tahun 2006 tentang Pedoman Pengelolaan Keuangan Daerah.

Menteri Dalam Negeri, Peraturan Menteri Dalam Negeri Nomor 17 Tahun 2007 tentang Pedoman Pengelolaan Barang Milik Daerah. 
Republik Indonesia, Undang-undang RI Nomor 17 Tahun 2003 tentang Keuangan Negara.

Republik Indonesia, Undang-undang RI Nomor 1 Tahun 2004 tentang Perbendaharaan Negara.

Republik Indonesia, Undang-undang RI Nomor 32 Tahun 2004 tentang Pemerintahan Daerah

Republik Indonesia, Undang-undang RI Nomor 33 Tahun 2004 tentang Perimbangan Keuangan antara Pemerintah Pusat dan Daerah.

Republik Indonesia, 2005. Peraturan Pemerintah Nomor 58 Tahun 2005 tentang Pengelolaan Keuangan Daerah.

Republik Indonesia, Peraturan Pemerintah Nomor 24 Tahun 2005 tentang Standar Akuntansi Pemerintahan (SAP).

Republik Indonesia, Peraturan Pemerintah Nomor 71 Tahun 2010 tentang Standar Akuntansi Pemerintahan (SAP).

Warisno, 2009, Faktor-faktor yang mempengaruhi Kinerja Satuan Kerja Perangkat Daerah dilingkungan Pemerintah Provinsi Jambi. 